\title{
Occupational safety and health management in developing countries
}

DOI:

10.1080/10803548.2018.1482649

\section{Document Version}

Accepted author manuscript

Link to publication record in Manchester Research Explorer

\section{Citation for published version (APA):}

Simukonda, W., Manu, P., Mahamadu, A. M., \& Dziekonski, K. (2018). Occupational safety and health management in developing countries: a study of construction companies in Malawi. International Journal of Occupational Safety and Ergonomics. https://doi.org/10.1080/10803548.2018.1482649

\section{Published in:}

International Journal of Occupational Safety and Ergonomics

\section{Citing this paper}

Please note that where the full-text provided on Manchester Research Explorer is the Author Accepted Manuscript or Proof version this may differ from the final Published version. If citing, it is advised that you check and use the publisher's definitive version.

\section{General rights}

Copyright and moral rights for the publications made accessible in the Research Explorer are retained by the authors and/or other copyright owners and it is a condition of accessing publications that users recognise and abide by the legal requirements associated with these rights.

\section{Takedown policy}

If you believe that this document breaches copyright please refer to the University of Manchester's Takedown Procedures [http://man.ac.uk/04Y6Bo] or contact uml.scholarlycommunications@manchester.ac.uk providing relevant details, so we can investigate your claim.

\section{OPEN ACCESS}




\section{OCCUPATIONAL SAFETY AND HEALTH MANAGEMENT IN DEVELOPING COUNTRIES: A STUDY OF CONSTRUCTION COMPANIES IN MALAWI}

${ }^{a}$ Wakisa Simukonda, ${ }^{b}$ Patrick Manu*, ${ }^{\text {b }}$ Abdul-Majeed Mahamadu, and ${ }^{b}$ Krzysztof Dziekonski

${ }^{a}$ Faculty of Built Environment, University of Malawi-The Polytechnic, Blantyre, Malawi.

${ }^{\mathrm{b}}$ Department of Architecture and the Built Environment, University of the West of England, Bristol, BS16 1QY, United Kingdom.

${ }^{*}$ Corresponding Author: Dr Patrick Manu

Email: Patrick.Manu@uwe.ac.uk

The Version of Record of this manuscript has been published and is available in the International Journal of Occupational Safety and Ergonomics, published on $30^{\text {th }}$ May 2018, at https://www.tandfonline.com/doi/abs/10.1080/10803548.2018.1482649 


\section{Abstract}

Purpose: Whilst occupational safety and health $(\mathrm{OSH})$ management is recognised as an important mechanism for addressing poor OSH performance, limited empirical insight is available on OSH management by construction companies in sub-Saharan Africa. This study investigated OSH management by construction companies (i.e. contractors) in Malawi in order to unpick implementation issues that need attention.

Materials and methods: $46 \mathrm{OSH}$ management practices were probed through a survey of contractors.

Results: Implementation of OSH practices amongst contractors is low, particularly for practices related to the policy, organising, measuring and reviewing, and auditing elements of OSH management. Company size, is associated with implementation of nearly a half of the $46 \mathrm{OSH}$ practices. Certification of company to Standard No. OHSAS 1800:2007 is associated with the implementation of fewer practices.

Conclusions: OSH management improvement efforts would need to focus on the elements with particularly low implementation of practices as well as include initiatives that focus on helping micro enterprises to improve their OSH management. Association between business characteristics and $\mathrm{OSH}$ management may be more evident with certain elements such as the organising element. Furthermore, certification to Standard No. OHSAS 1800:2007 may not necessarily translate into greater implementation of $\mathrm{OSH}$ management practices, especially in developing countries.

Keywords: construction; developing countries; occupational safety and health management; sub-Saharan Africa; survey.

\section{Introduction}

Construction workers' occupational safety and health $(\mathrm{OSH})$ continues to be a problem in several countries as the industry is characterised by high numbers of work-related injuries and illnesses [1-4]. In the US, the construction industry was responsible for 774 and 991 fatal injuries in 2010 and 2016, respectively [5,6]. In the UK, the Health and Safety Executive (HSE) [7] states that $6 \%$ of construction workers either suffer from illnesses or sustain injuries caused or aggravated by the nature of their construction work, annually.

Construction sites in developing countries are not in the state of utopia either. The fatal injury rate (i.e., the number of occupational fatal injuries per 100,000 workers) and accidents rate (i.e., the number of occupational accidents per 100,000 workers) for subSaharan African countries are estimated to be 21 per 100,000 workers and 16,012 per 100,000 workers, respectively [8]. The construction industry is ranked second in Tanzania [9] and third in South Africa [8] as the largest contributor to occupational accidents. Whilst it is responsible for $9.6 \%$ of fatal injuries in Tanzania [10], the industry accounted for 376 fatal injuries in South Africa for the period of 2004 to 2008 [8]. Statistics for construction safety and health accidents in Malawi are not available because data is non-existent $[11,12]$. However, the International Labour Organisation 
(ILO) OSH estimates for Malawi in all occupations indicate that the number of accidents causing more than 3 days of absence from work was almost a million for the period of 2004 to 2009 [13], an average of 200,000 accidents per year. Inferring from the construction $\mathrm{OSH}$ situation in Tanzania and South Africa, which share similar characteristics with Malawi, the construction OSH situation in Malawi can also be said to be poor.

The economic impacts of occupational injuries and illnesses on enterprise performance are unprecedented. Among others, occupational injuries and illnesses disrupt production process, deteriorate human capital and damage the corporate image $[2,14,15]$. In the UK, occupational injuries and illnesses in construction were associated with an estimated loss of 1.7 million working days and GBP 0.9 billion for the period of 2014 to 2015 and 2013 to 2014, respectively [7]. Overall, occupational injuries and illnesses account for a loss of about $1 \%$ to $6 \%$ of a nation's gross domestic product [16] and about $4 \%$ of the global gross domestic product [12].

However, occupational safety and health management systems (OSH MSs) have been recognised as an important means for improving OSH performance. OSH MSs are reported to promote safety climate and corporate image, increase production and prevent the loss of human capital and associated costs [14,17-19]. Realising the importance of OSH management, the Malawi government launched a five-year national OSH programme to improve safety and health in workplaces in line with the Malawi decent work agenda for the period of 2011 to 2016 [12]. Its overarching goal was to achieve a continual reduction of at least $5 \%$ in occupational fatal injuries through systematic management of $\mathrm{OSH}$, annually [12]. The specific objectives of the programme endeavoured to improve OSH management systems and infrastructure, enhance information management and dissemination, increase awareness of occupational tuberculosis and other diseases, and strengthen the legal OSH framework [12]. These objectives were designed to be realised through the formulation of a coherent national $\mathrm{OSH}$ policy, harmonisation of $\mathrm{OSH}$ legislation, increasing $\mathrm{OSH}$ awareness and improving accidents data recording system, among others [12].

While an evaluation of the impact of the programme is yet to be released, a textual analysis of the programme reveals some potential inadequacies. For instance, the OSH programme lacks initiatives targeting micro, small and medium-sized firms (SMEs) which according to previous studies [e.g., 20,21] struggle with OSH management. Furthermore, the programme neither explicitly mentions OSH MSs nor provides direction as to which elements and practices of OSH management need attention so that improvement efforts can be targeted at those elements and practices. OSH management still depends on compliance with minimum regulations, presumably unknown by consumers and sluggishly enforced by authorities [13]. Additionally, studies have highlighted the dearth of literature on $\mathrm{OSH}$ management in construction within the sub-Saharan African region [22,23]. In Malawi, the only published study on OSH in the construction industry assessed the knowledge of legislation relative to safety and health and safety culture among construction industry professionals [11]. Thus, an in-depth analysis of OSH management practices of construction firms in Malawi is non-existent, creating a knowledge gap which needs to be addressed. Hence, the focus of this study is an investigation of OSH management practices implemented by construction firms in Malawi in order to unpick implementation issues that need attention. 


\section{Occupational safety and health management systems}

The concept of OSH MSs as a key prevention strategy for occupational accidents emerged in the 1990's. The major industrial accidents (i.e., the 1974 Flixborough explosion in UK, the 1984 Bhopal leak in India and the 1986 Chernobyl in Ukraine) had formative influences on the concept [24-27]. The earliest solutions for improving workplace safety and health focused on procedures for the safe physical environment [28]. However, it was acknowledged that the industries' nature of operations which were becoming more dynamic and complex necessitated the application of new approaches to maintain safety and health $[26,27]$. Workplace organisational factors such as safety and health management activities which ensure swift response to imponderables and random changes in businesses through continuous improvement of performance were identified as possible solutions [26,27]. Meanwhile, British Standard Institution (BSI) defines OSH MSs as 'part of an organisations management system used to develop and implement its OSH policy and manage it OSH risks' [29,p.3]. Anchoring its foundation in management system, Ghallagher et al. [30] suggest that OSH MSs should comprise defined objectives, inter-related elements, links with other organisations' systems and requirements for system maintenance. As the fundamental property of the system is the interdependence of its variables, the authors argue that the linking of these components to achieve OSH objectives is what underlines OSH MSs. Recently, many authors have advocated for the amalgamation of multiple systems into a single integrated management system (IMS). Jorgensen et al. [31] state that operating separate management systems is wasteful as it entails significant financial commitments on the part of the organisation. As a result, some organisations have amalgamated at least two parts of quality, environmental and safety and health management systems in order to optimise resource utilisation [1,31,32]. Despite the appetite for IMS, separate management systems remain in use, e.g., Standard No. OHSAS 18001:2007 for OSH management.

\subsection{Systematic OSH MSs}

Various OSH management models have been developed by public and private institutions as well as individuals. Most of these models are based on the HSE model [33] and a few have been further improved. Therefore, only a handful of models are relevant and are discussed in chronological order.

\subsubsection{Successful health and safety management (HSG 65)}

Officially known by its series number HSG 65, the model was first published in 1991 and revised in 1997 by HSE [33]. It is a universal non-mandatory blueprint, conceived as OSH standard for all sectors of occupations [34]. Its objective is to minimise occupational accidents through an effective and proactive management structure [33,34]. It embraces OSH as an integral part of the management function [34]. The model has six elements designated as policy, organising, planning, measuring, auditing and reviewing (POPMAR), which are linearly sequenced except for auditing which represents a supra system element [33-35]. Based on HSE [33], the elements are defined as follows:

- Policy: The overall OSH philosophy and fundamental principles crafted in line with the organisation's core activities and current legislation. 
- Organising: Designing an effective management structure and allocating resources for delivery of $\mathrm{OSH}$ policy.

- Planning and implementation: Sequencing action steps to guide implementation of safety and health policy through a systematic OSH management structure and the actual operation.

- Measuring performance: Actual measurement of performance against the set standards to determine areas which need improvement through active and reactive monitoring.

- Auditing: Conducting an independent audit of the performance of the overall OSH MSs to ensure its perfect functioning for the continuous improvement of the OSH MS.

- Reviewing performance: The systematic review of the effectiveness of OSH MSs based on feedback from measuring and auditing and applying lessons learnt to improve the systems' performance.

Whilst the model is easier to comprehend, it has been criticised for lack of clarity and specification of its inputs and outputs, lack of empirical evidence to support its practicality and redundancy of auditing and measuring performance $[35,36]$. Nevertheless, the model is the basis of succeeding OSH management models.

\subsubsection{Standard No. OHSAS 18001:2007}

In late 1990's, OSH MSs certification was becoming a long-range strategy for organisation's business competition and conformance in a number of areas [32,36]. As a result, organisations started demanding OSH MSs against which their safety and health management systems could be evaluated and certified [29,37]. This led to the development of Standard No. OHSAS 18001:1999 which was revised in 2007. The main objective of the standard is to create and maintain a safe working environment [37] and promote good health of workers $[18,38]$ through systematic safety and health management $[37,39]$. Its main elements include OSH policy, planning, implementation and operation, checking and corrective action, and management review [29]. The standard is based on Deming's philosophy of plan, do, check, act (PDCA) process which promotes principles of continuous improvement and internalisation of safety and health into core business management $[17,35,37]$. Other standards (e.g., Standard No. ISO 9001:2000 (quality management system-requirements) and Standard No. ISO 14001:2004 (environmental management system-requirements with guidance for use)) adopt the same approach and therefore are compatible with Standard No. OHSAS 18001:2007 [40]. Despite being criticised for lack of cogent direction and clarification on the purpose of non-financial audit [35], Standard No. OHSAS 18001:2007 is a compellable international OSH MS of choice [29].

\subsubsection{McDonald's et al. safety management model}

The model coalesces salient components of the HSE model and safety culture of Pidgeon and O'Leary [33,41]. It is a self-regulatory feedback model with seven elements divided into two levels of safety management functions, namely, operational performance and system auditing [35]. Operational performance comprises policy, 
standards, planning and organising and normal operational practice and the whole system is subject to audit and review [41]. Overall, the model is comprehensible and its linear-structured elements are easy to follow. Nevertheless, the model lacks clear interrelated relationships among its elements and supplementary pragmatic evidence [35] to corroborate its effectiveness in addressing safety issues in its niche.

\subsubsection{Perezgonzalez's safety management model}

Perezgonzalez's [35] model presents an enhanced hypothetical safety management model by exploiting gaps in the HSE [33] and McDonald's et al. [41] models. Its main elements include policy, planning and organisation, operational practice and monitoring [35]. It also has pre-adjustment and change and post adjustment and change stages which inform operational practice and organisational OSH goals at the higher level in order to influence desired outcomes [35].

\subsubsection{ILO-OSH 2001}

The model reflects the universal principles enshrined in ILO's OSH model particularly OSH convention of 1981 (i.e., No. 155) [26]. It is intended to be used at both the organisational and the national levels, non-mandatorily $[26,27]$. At the organisational level, the guidance promotes incorporation of OSH MSs components into the organisational overall policy and management arrangements while at the national level, it encourages the establishment of a national framework for OSH MSs supported by national laws and regulations [27]. The model has five elements including OSH policy, planning, implementation, measuring and evaluation, and management review [26,27].

\subsubsection{HSE managing for health and safety}

The HSE [42] OSH management model abandons the POPMAR structure and adopts a plan, do, check, act (PDCA) approach. Like previous versions, the model seeks to help organisations develop and implement OSH management arrangements while abiding by the law [42]. The elements of this model include plan (i.e., policy and planning), do (i.e., risk profiling, organising and implementing the plan), check (i.e., measuring performance and investigating incidents, and act (i.e., learning lessons and reviewing performance) [33].

Overall, the majority of the models are based on the original model of HSE [33] in terms of their elements and corresponding safety and health practices. As such, the models inherit the weaknesses of the HSE [33] model, particularly by presenting a management process rather than a management system for addressing the OSH incidences. Table 1 summarises the key elements of the models discussed above.

\section{[Insert Table 1 approximately here]}

\subsection{Effectiveness of OSH MSs: The research evidence}

Robson et al. [17] state that the current strand of literature does not unequivocally demonstrate the practical effectiveness of OSH MSs in addressing safety and health challenges. Nevertheless, there are arguments in favour of the value of OSH MSs in addressing safety and health challenges in all sectors, including the construction industry. Robson et al. [17] conducted a systematic literature review of thirteen articles 
on the effectiveness of OSH MSs in addressing occupational accidents. The findings revealed that accidents frequency decreased by $24 \%$ to $34 \%$ and $18 \%$ for voluntary and mandatory OSH MSs, respectively [17]. In addition, $13 \%$ to $52 \%$ decrease in workers' compensation was recorded over a period of three years [17]. Yoon et al. [19] conducted a study on the effect of OSH MSs on work-related accident rates in the South Korean construction industry. They found annual average accident rates of 0.18 and 0.30 victims per 100 employees for OSH MS certified and non-certified construction companies, respectively [19]. Furthermore, the fatal accident rates for OSH MS certified companies plummeted by $10.3 \%$ when compared to non-certified companies [19]. On the other hand, Abad et al. [2] studied the impact of Standard No. OHSAS 18001:2007 on safety performance and labour productivity in 149 Spanish companies between 2006 and 2009 . The study revealed a $1.43 \%$ decrease in the rate of accidents, a $4.21 \%$ increase in labour productivity and a deeper embedded safety culture as a result of an extra year of safety experience, yielding a further $0.80 \%$ reduction in accidents rates [2]. These studies and others, demonstrate the effectiveness of OSH MSs in addressing $\mathrm{OSH}$ management performance challenges.

\section{Research Design}

The overarching aim of the study was to investigate the $\mathrm{OSH}$ management practices implemented by construction companies in Malawi in order to identify the safety and health management elements and practices which need improvement. In order to achieve the aim, a quantitative research design, in particular, a survey was adopted. The quantitative survey was used due to its suitability for obtaining a generalised view of a phenomenon [43], which in the case of this study is the OSH management practices of construction companies in Malawi. The survey strategy has also been used by previous studies that examined OSH management practices by construction companies in other developing countries [20,21]. This study targeted senior company management personnel such as directors, OSH managers and engineers as they are more likely to have good knowledge of their companies' safety and health management practices [21].

\subsection{Survey design}

A questionnaire instrument was designed for the survey. The questionnaire comprised multiple questions with fixed response categories, i.e., dichotomous yes or no and multiple choices, as well as open-ended questions. The questionnaire comprised three sections as follows: (a) introduction (i.e., a prefatory section containing general instructions for filling the questionnaire); (b) respondents' and company profile (i.e., sought information related to professional roles, experience, company size and age) which was used for establishing the relationship between business characteristics and implementation of OSH management practices; and (c) business safety and health management practices. Drawing from practices within OSH management elements (i.e., summarised in Table 1), the last section elicited responses on the $\mathrm{OSH}$ management practices implemented by construction companies in Malawi. A total of 46 $\mathrm{OSH}$ management practices were probed.

Prospective respondents were drawn from a list of construction firms compiled by Malawi's National Construction Industry Council (NCIC) and registered for 2016 to 2017 financial year. The list comprised 1527 construction firms registered in building, civil and electrical engineering categories. A simple random sampling (SRS) aided by Microsoft Excel version 2016 was employed to draw a list of 320 firms from the population. Using 
researchers' contacts in Malawi, the email addresses of the sampled contractors were obtained for the administration of the questionnaire. Where this was unsuccessful, the selected contractors were randomly replaced to maintain the sample size. A softcopy of the questionnaire together with a link to an online version hosted by Bristol Online Survey (BOS) was emailed to the selected contractors. Accompanying the questionnaire was a request for a company personnel in management role to complete the questionnaire.

\subsection{Data analysis}

The data was screened and coded in order to obtain numerical values for analysis. Subsequently, the data was exported to IBM Statistical Package for Social Science (SPSS) version 23.0. The level of implementation of OSH management practices by the construction companies was assessed based on Manu et al. [21] categorisation of the implementation levels, i.e., low implementation (i.e., where $0 \%$ to $49 \%$ of companies implement a practice), moderate implementation (i.e., where $50 \%$ to $59 \%$ of companies implement a practice) and high implementation (i.e., where over $70 \%$ of companies implement a practice). The procedure adopted for establishing the associations between business characteristics and the implementation of $\mathrm{OSH}$ management practices involved using Pearson's $X^{2}$ test as employed by Kheni et al. [20] and Manu et al. [21]. The dependent variables (i.e., implementation of OSH management practices) were dichotomous yes or no and were defined as yes (i.e., implementation of OSH management practice) and no (i.e., non-implementation of $\mathrm{OSH}$ management practice). Three hypotheses were formulated and tested. The hypotheses include: (a) $H_{1}$ : certification to Standard No. OHSAS 18001:2007 will be significantly associated with implementation of OSH management practice; (b) $\mathrm{H}_{2}$ : company age (i.e., the number of years the company has been in operation) will be significantly associated with implementation of OSH management practice [20]; and (c) $H_{3}$ : company size will be significantly associated with implementation of $\mathrm{OSH}$ management practice [20].

4. Results

The results of the study are presented below under three sections: (a) respondents' and company profile; (b) OSH management practices; and (c) the relationship between the business characteristics and implementation of $\mathrm{OSH}$ management practices.

\subsection{Respondents' and company profile}

The response rate and professional roles of the respondents are shown in Tables 2 and 3 , respectively. The response rate is regarded as good considering that the normal response rate in construction ranges from $20 \%$ to $30 \%$ [44]. The mean working experience (in years) of the respondents is 7.0 and a banded distribution of their experience is also shown in Figure 1. Taken together, the responses provided by the respondents can thus be considered to be an accurate depiction of their companies' $\mathrm{OSH}$ management practices.

[Insert Table 2 approximately here] 
[Insert Figure 1 approximately here]

Figure 1: Respondents' working experience

(Note: Sum of \% is less than $100 \%$ due to non-response by some participant)

Table 4 summarises the companies' profile. Over $70 \%$ of the companies are micro and small companies. This is in consonance with the demographic profile of companies in the construction industry of other countries $[20,21,45]$, where the sector is largely dominated by micro and small enterprises. Just like in other countries [21], the category of firm's registration in Malawi is not mutually exclusive as companies sometimes undertake multiple work categories such as building works and civil engineering works as evidenced by the results in Table 4 . Figure 2 also shows that fewer than $20 \%$ of the companies are certified to Standard No. OHSAS 18001:2007.

\section{[Insert Table 4 approximately here]}

[Insert Figure 2 approximately here]

Figure 2: Certification to Standard No. OHSAS 18001: 2007 by construction companies

(Note: Sum of \% is less than $100 \%$ due to non-response by some participants)

\section{2 $\mathrm{OSH}$ management practices}

Table 5 presents results of statistical analysis of OSH management practices. As previously mentioned the practices were dichotomous yes or no and were defined as follows: $1=y e s$ (i.e., implementation of safety and health management practice) and 0 $=n o$ (i.e., non-implementation of safety and health management practice). In order to show the OSH management practices implemented across the sample of construction firms, attention is drawn to the percentage of companies that implement a practice. As highlighted earlier, the levels of implementation are categorised into low implementation (i.e., $0 \%$ to $49 \%$ ), moderate implementation (i.e., $50 \%$ to $69 \%$ ) and high implementation (i.e., over $70 \%$ ) [21]. The findings are discussed below under the key elements of safety and health management.

Policy: This element assessed two safety and health management practices. The findings indicate low implementation for pol1 and pol2 (i.e., $44.0 \%$ and $41.3 \%$, respectively).

Organising: Fourteen practices were assessed within this element. Org3 recorded high implementation (i.e., $70.7 \%$ ) while org1 and org9 showed moderate implementation (i.e., $52.0 \%$ and $56.0 \%$, respectively). Low implementation was registered for the remaining eleven practices. 
Risk assessment: This element assessed five practices. Risk5 recorded high implementation with $80.0 \%$ while risk 1 and risk 2 showed moderate implementation. Low implementation was recorded on risk3 and risk4.

Planning: Five practices were assessed within this element. High implementation was seen for pln2 (i.e., 74.7\%). Pln1 and pln3 registered moderate implementation while pln4 and pln5 recorded low implementation.

Implementing: This element assessed twelve practices. Practices impl7, impl8 and impl9 recorded high implementation, i.e., $80.0 \%, 92.0 \%$ and $89.3 \%$, respectively. The other practices registered either moderate or low implementation.

Measuring and reviewing performance: Five practices were examined under this element. High implementation was observed on meas\&rev3 (i.e., 70.7\%) while meas\&rev4 recorded moderate implementation (i.e., 61.3\%). The other three practices registered low implementation.

Auditing: All three practices under this element, i.e., aud1, aud2 and aud3 recorded low implementation with $33.3 \%, 12.0 \%$ and $44.0 \%$, respectively.

Overall, the observed level of implementation is summarised as follows: low $=29$ practices, moderate $=10$ practices and high $=7$ practices.

\section{[Insert Table 5 approximately here]}

4.3 Associations between company characteristics and safety and health management practices

The findings of the Pearson's $x^{2}$ test determining significant statistical associations between business characteristics and implementation of OSH management practices are presented in Tables 6,7 and 8. The conventional statistical significance level of $p=$ 0.050 was adopted [46]. The $H_{0}$ (i.e., no association between variables) was rejected if the significance level was small (i.e., $p<0.050$ ). For the sake of brevity, the tables present only $\mathrm{OSH}$ management practices which are significantly associated with business characteristics.

4.3.1 Association between certification to Standard No. OHSAS 18001:2007 and implementation of safety and health management practices

The results of the association between certification to Standard No. OHSAS 18001:2007 and implementation of OSH practices are presented in Table 6. The observed results revealed significant association between certification to Standard No. OHSAS 18001:2007 and implementation of nine OSH management practices (i.e., pol1, org1, org2, org4, org6, org11, pln1, pln4, and impl11). Therefore, the first hypothesis (i.e., certification to Standard No. OHSAS 18001:2007 will be significantly associated with the implementation of $\mathrm{OSH}$ management practice) was accepted for these practices. The superscript letters (i.e., $c$ and d) of the counts in Table 6 show the results of $z$-test that compares column proportions (i.e., comparison between the $1 \%$ within practice' for implementation of a practice and '\% within practice' for non-implementation of that practice) [46]. These superscripts enable interpretation of the nature of the association. Different superscript letters indicate that the proportion within practice for implementation and the proportion within practice for non-implementation are 
significantly different [46]. For example, for pol1, the different superscript letters for 36 and 21 means that $90.0 \%$ is significantly different from $67.7 \%$. Similarly, the $10.0 \%$ and $32.3 \%$ are significantly different. Thus the proportion of companies not certified to Standard No. OHSAS 18001:2007 that do not implement pol1 (i.e., 90.0\%) is significantly greater than the proportion of non-certified companies that implement pol1 (i.e., 67.7\%). Conversely, the proportion of companies certified to Standard No. OHSAS 18001:2007 that do not implement pol1 (i.e., 10.0\%) is significantly less than the proportion that implement pol1 (i.e., 32.3\%). The pattern of association thus suggests that companies that are certified to Standard No. OHSAS 18001:2007 are more likely to implement pol1. This pattern of association applies to the other practices in Table 6 as shown by the different superscript letters for the counts of those practices.

4.3.2 Association between company age and the implementation of safety and health management practices

The cross-tabulation (see Table 7), presents findings of the association between company age and the implementation of OSH management practices. The findings reveal that company age is significantly associated with $10 \mathrm{OSH}$ practices, namely, pol2, org1, org3, org7, org8, org13, risk2, pln1, impl11 and aud1. As such, the second hypothesis (i.e., company age will be significantly associated with the implementation of OSH management) is accepted for these practices. An examination of the superscript letters of the counts in Table 7 reveals an overall pattern such that, as companies get older (i.e., company age increases), the more likely they are to implement these practices. For instance for pol2, a significantly greater proportion of the companies aged up to 10 years do not implement pol2. Amongst companies aged between 11 and 50 years there is no significant difference between the proportion that implement and the proportion that do not implement pol2. However, for companies aged over 50 years, a significantly greater proportion implement pol2.

4.3.3 Association between business size and implementation of $\mathrm{OSH}$ management practices

The contingency Table 8 presents findings of the association between company size and implementation of $\mathrm{OSH}$ management practices. Likelihood ratio was used to interpret the results because more than $20 \%$ of the expected counts were less than 5 [46]. The findings reveal significant associations between company size and $20 \mathrm{OSH}$ management practices. Therefore, the third hypothesis (i.e., company size will be significantly associated with the implementation of $\mathrm{OSH}$ management practice) is accepted for these practices. An examination of the superscript letters of the counts in Table 8 reveals a general pattern of association such that, as company size moves from micro to medium, a company is more likely to implement those practices. For example, for pol1, pol2, org1, org2, org3, org4 and others, a significantly greater proportion of micro companies do not implement these practices. However, a significantly greater proportion of medium-sized companies implement those practices. 
[Insert Table 7 approximately here]

[Insert Table 8 approximately here]

\section{Discussion}

As highlighted above, the findings can be considered to give a credible reflection of the firms' OSH management practices in view of the profile of the respondents, i.e., almost all of the respondents are in construction management related roles and they also have reasonable working experience in their roles. Similar respondents' profiles were observed by Kheni et al. [20] and Manu et al. [21] in their studies on OSH management practices of construction businesses in Ghana, Malaysia, Thailand and Cambodia. Micro-sized firms and SMEs constituted over $90 \%$ of the companies which is again in consonance with previous studies [21,22]. Many of these companies were registered in over 1 billion MWK on NCIC scale of classification of contractors. Companies in this class are considered capable of executing large projects either independently or in partnerships.

The study has revealed that the implementation of $\mathrm{OSH}$ management practices by construction firms in Malawi is generally poor. The general low implementation of OSH management practices observed in this study is in accord with the study by Takala et al. [47] which indicated an inverse relationship between national competitiveness (i.e., as measured by the World Economic Forum [48] global competitiveness index) and rate of occupational fatal accidents. National competitiveness is defined as, 'the set of institutions, policies and factors that determine the level of productivity' [48, p. ix]. This inverse relationship suggests that countries, like Malawi, which have a low competitiveness index [48], would have higher rates of occupational fatal accidents and by inference also have weaker systems for managing $\mathrm{OSH}$.

As summarised in Table 9, policy and auditing elements of OSH management are the least considered, with all practices within these elements registering low implementation. Other elements with unsatisfactory implementation levels of the $\mathrm{OSH}$ practices are organising (i.e., 78.6\%), measuring and reviewing performance (i.e., 60\%) and implementing (i.e., $50 \%$ ). The low level of implementation of OSH practices within these elements is not surprising considering that the majority of firms are micro and SMEs. The implementation of OSH practices within these elements requires a commitment of resources. However, previous studies have noted that SMEs usually lack resources to enable them to invest in $\mathrm{OSH}$ management and other areas $[22,49]$. The observed association between the size of business and implementation of $\mathrm{OSH}$ management practices is thus in line with the extant literature. Kheni et al. [20] and Manu et al. [21] similarly reported associations between company size and implementation of OSH management practices.

In addition, the results of the Pearson's $X^{2}$ test revealed that company age and firms' certification to Standard No. OHSAS 18001:2007 are significantly associated with the implementation of some OSH practices, particularly the practices within the organising 
element. Thus younger firms and companies without certification to Standard No. OHSAS 18001:2007 are less likely to implement those OSH management practices. The association between certification to Standard No. OHSAS 18001:2007 and implementation of safety and health management practices is indirectly supported by the work of Yoon et al. [19] and Abad et al. [2] in which OSH management certification was associated with better OSH performance, and by inference better implementation of OSH management. However, it is interesting to note that certification to Standard No. OHSAS 18001:2007 is associated with the implementation of less than a quarter of the 46 practices (i.e., nine practices). Whilst this suggests that certification to Standard No. OHSAS 18001:2007 may be of low added value to OSH management by construction companies in Malawi, a plausible explanation for the observed limited association could be the cost involved in sustaining the requirements/expectations of the certification. This view is supported by studies which have reported that cost of implementation is a major barrier to the implementation of international management systems (e.g., environmental management systems) in developing countries [50,51].

The association between certification to Standard No. OHSAS 18001:2007 and the limited number of practices also raises a concern about: (1) the quality of the $\mathrm{OSH}$ management audits undertaken by the certifying organisations; and (2) the quality of routine monitoring undertaken by the certifying organisations to check that the requirements of the certification are being upheld. The auditing and routine monitoring are lax as shown by Table 5 (i.e., all the practices within auditing element registered low implementation). Furthermore, there was no association between certification to Standard No. OHSAS 18001:2007 and the implementation of practices within the auditing element (see Table 6). Thus, regarding (internal or external) OSH management auditing, there is no significant difference between certified and non-certified companies. This further confirms a laxity in the auditing and routine monitoring undertaken by certifying organisations.

Literature shows that a national OSH programme can be instrumental as part of efforts to improve OSH performance [52,53]. For instance, an evaluation by the HSE Construction Division [53], in respect of the UK nation-wide safety and health initiative, namely, 'Revitalising Health and Safety' (RHS), showed that injury rates in construction persistently met the national RHS targets. Furthermore, an evaluation of the Vietnamese national OSH programme for the period 2006 to 2010 highlighted several impacts of the programme including: (a) a reduction in the rate of fatal injuries; (b) a decrease in the number of new cases of occupational diseases; (c) an increased attention amongst businesses to the development of safety and health management system; and (e) an increased awareness amongst enterprises about the importance of safety and health to production and productivity [52]. A subsequent iteration of the Vietnamese programme for the period 2011 to 2015 included specific objectives which focused on SMEs (e.g., a target to attain an annual average increase of 2000 SMEs which effectively apply safety and health management system) [52]. Such recognition of the need to pay attention to OSH management by SMEs could be useful, given the tendency for SMEs to lag in OSH management implementation as shown by this study and others [20,21]. However, referring to the Malawi national OSH programme, the programme seems to parade a one size fits all approach as it does not discriminate businesses based on characteristics such as size as recommended by Kheni et al. [20]. This approach can be ineffective in the construction sector due to the varied nature of construction activities/works and businesses undertaking those activities/works [54]. As 
a result, it would be helpful for the Malawi national OSH programme to incorporate initiatives that seek to strengthen the capacity of micro companies in $\mathrm{OSH}$ management.

[Insert Table 9 approximately here]

\section{Conclusion}

Against the backdrop of the poor status of $\mathrm{OSH}$ in construction, particularly in developing countries, and coupled with the significance of $\mathrm{OSH}$ management by companies to $\mathrm{OSH}$ performance, this study inquired into the implementation of OSH management practices by contractors in Malawi. Overall, a low level of implementation of $\mathrm{OSH}$ management practices was observed. The least implemented $\mathrm{OSH}$ management practices were also observed to be related to the policy, organising, measuring and reviewing, and auditing elements of OSH management. Additionally, business characteristics, namely, company size, age and certification to Standard No. OHSAS 18001:2007 were associated with the implementation of some OSH practices, especially practices related to the organising element of OSH management. However, the association between company size and the implementation of $\mathrm{OSH}$ practices is more prominent. It would therefore be helpful if efforts aimed at improving $\mathrm{OSH}$ management within the construction sector of Malawi focus on the OSH management elements with particularly low implementation of practices. Additionally, such efforts would need to include initiatives that focus on helping micro enterprises to improve their $\mathrm{OSH}$ management. Aligned to this, subsequent iterations of the Malawi national OSH programme could incorporate interventions targeted at these $\mathrm{OSH}$ management elements as well as micro businesses.

The findings also contribute to the wider discourse on OSH management by suggesting that the association between business characteristics and OSH management may be more evident with certain elements such as the organising element. Furthermore, within the context of developing countries (where cost is a major barrier to implementation of international management systems), certification to Standard No. OHSAS 1800:2007 may not necessarily translate into greater implementation of $\mathrm{OSH}$ management practices. Organisations that offer certification services would therefore need to tighten the quality of their $\mathrm{OSH}$ management audits and routine monitoring.

\section{REFERENCES}

[1] Zeng S, Tam W, Tam C. Towards occupational health and safety systems in the construction industry in China. Saf Sci. 2008;46(8):1155-1168.

[2] Abad J, Lafuente E, Vilajosana J. An assessment of the OHSAS 18001 certification process: Objective and drivers and consequences on safety performance and labour productivity. Saf Sci. 2013;60:47-56.

[3] Sousa V, Almeida NM, Dias LA. Risk-based management of occupational safety and health in the construction industry-Part 1: Background knowledge. Saf Sci. 2014;66:75-86. 
[4] Chandra HP. Initial investigation for potential motivators to achieve sustainable construction safety and health. Proc Eng. 2015;125:103-108.

[5] Zhou Z, Goh Y, Li Q. Overview and analysis of safety management studies in the construction industry. Saf Sci. 2015;72:337-350.

[6] Bureau of Labor Statistics [Internet]. Washington (DC): Bureau of Labor Statistics; 2017. Census of fatal occupational injuries summary, 2016; 2017 Dec 17 [cited 2018 Jan 5]; [about 2 screens]. Available from: https://www.bls.gov/news.release/cfoi.nr0.htm

[7] Health and Safety Executive. Health and safety in construction sector in Great Britain 2014/15. Bootle: Health and Safety Executive; 2015.

[8] Construction Industry Development Board. Construction health and safety in South Africa. Pretoria: Construction Industry Development Board; 2008.

[9] Mbuya E, Lema NM. Towards development of framework for integration of safety and quality management techniques in construction project delivery process. In: Boshoff $F$, editor. Proceedings of the 1st International Conference of CIB W107; 2002 Nov 11-13; Stellenbosch. Delft: CIB; 2002.

[10] Kitumbo HI, Kirenga AP. Construction industry in Tanzania. Afr Newsl Occup Health Saf. 2001;11(1):8-9.

[11] Chiocha C, Smallwood J, Emuze J. Health and safety in the Malawian construction industry. Acta Structilia. 2011;18(1):68-80.

[12] International Labour Organisation. Malawi national occupational safety and health programme 2011-2016. Lusaka: International Labour Organisation; 2011.

[13] International Labour Organisation. Malawi country profile on occupational safety and health 2009. Lusaka: International Labour Organisation; 2009.

[14] Frick K. Worker influence on voluntary OHS management systems - Review of its ends and means. Saf Sci. 2011;49(7):974-987.

[15] Santos G, Barros S, Mendes F, Lopes N. The main benefits associated with health and safety management systems certification in Portuguese small and medium enterprises post quality management system certification. Saf Sci. 2013;51(1):29-36.

[16] Nenonem N, Saarela K, Takala J, et al. Global estimates of occupational accidents and work-related illnesses in 2014. Kallang: Workplace Safety and Health Institute; 2014.

[17] Robson LS, Clarke JA, Cullen K, et al. The effectiveness of occupational health and safety management systems interventions: A systematic review. Saf Sci. 2007; 45(3):329-353. 
[18] Fernandez-Muniz B, Montes-Peon JM, Vazquez-Ordas CJ. Occupational risk management under the OHSAS 18001 Standard: Analysis of perceptions and attitudes of certified firms. J Clean Prod. 2012; 24:36-47.

[19] Yoon SJ, Lin HK, Chen G, et al. Effect of occupational health and safety management system on work-related accident rate and differences of occupational health and safety management system awareness between managers in South Korea's construction industry. Saf Health Work. 2013;4(4):201209.

[20] Kheni NA, Dainty ARJ, Gibb AGF. Health and safety management in developing countries: a study of construction SMEs in Ghana. Constr Manage Econ. 2008;26(11):1159-1169.

[21] Manu P, Mahamadu A, Phung VM, et al. Health and safety management practices of contractors in South East Asia: A multi country study of Cambodia, Vietnam and Malaysia. Saf Sci. 2018;107:188-201.

[22] Kheni NA. Impact of health and safety management on safety performance of small and medium-sized construction businesses in Ghana [dissertation]. Loughborough: Loughborough University; 2008.

[23] Mwombeki FK. Roles when collaborating on enhancing construction site health and safety: Tanzania experience and way forward. In: Fang D, Choudhry RM, Hinze JW, editors. Proceedings of CIB W99 international conference on global unity for safety and health in construction; 2006 June 28-30; Beijing. Beijing: Tsinghua University Press; 2006. p. 419-427.

[24] Willey RJ, Crowl DA, Lepkowski W. The Bhopal tragedy: Its influence on process and community safety as practiced in the United States. J Loss Prev Proc. 2005;18(4-6):365-374.

[25] Vayrynen S, Hakkienen K, Niskanen T., editors. Integrated occupational safety and health management solutions and industrial cases. Cham: Springer; 2015.

[26] International Labour Organisation. OSH management system: A tool for continual improvement. Geneva: International Labour Organisation; 2011.

[27] International Labour Organisation. Guidelines on occupational safety and health management systems: ILO-OSH 2001. Geneva: International Labour Organisation; 2001.

[28] Lingard $\mathrm{H}$, Rowlingnson S. Occupational health and safety in construction project managements. Abingdon: Spon Press; 2005.

[29] British Standard Institution (BSI). Occupational health and safety management systems - requirements. London: BSI; 2007. Standard No. BS OHSAS 18001:2007. 
[30] Ghallagher C, Underhill E, Rimmer M. Occupational health and safety management systems: A review of their effectiveness in securing healthy and safe workplaces. Sydney: National Occupational Health and Safety Commission; 2001.

[31] Jorgensen TH, Remmen A, Mellado MD. Integrated management systems Three different levels of integration. J Clean Prod. 2006;14(8):713-722.

[32] Zutshi A, Sohal S. Integrated management system: The experiences of three Australian organisations. J Manuf Technol Manage. 2005;16(2):211-232.

[33] Health and Safety Executive. Successful health and safety management. 2nd ed. Bootle: Health and Safety Executive; 1997.

[34] Snowball D. Safety management system assessment criteria. In: IChemE Symposium Series No. 144; 1998 Nov 10-12. Rugby: Institution of Chemical Engineers; 1998; p. 53-64.

[35] Perezgonzalez J. Construction safety management, A systems approach. Dublin: ["publisher unknown"]; 2005.

[36] Hasle, P. and Zwetsloot, G. Editorial: Occupational health and safety management systems: Issues and challenges. Saf Sci. 2011;49(7):961-963.

[37] Bevilacqua M, Ciarapica FE, Sanctis ID. How to successfully implement OHSAS 18001: The Italian case. J Loss Prev Proc. 2016;44:31-43.

[38] Chen C, Wu G, Chuang K, et al. A comparative analysis of the factors affecting the implementation of occupational health and safety management systems in the printed circuit board industry in Taiwan. J Loss Prev Proc. 2009;22(2):210215.

[39] Vinodkumar M, Bhasi M. A study on the impact of management system certification on safety management. Saf Sci. 2011;49(3):498-507.

[40] Suarez-Garcia H. Quality, safety and environmental systems integration. Occup Health Saf (Waco, Tex.). 2001;70(11):56-56.

[41] McDonald N, Corrigan S, Daly C, et al. Safety management systems and safety culture in aircraft maintenance organisations. Saf Sci. 2000;34(1-3):151-176.

[42] Health and Safety Executive. Managing for health and safety. Bootle: Health and Safety Executive; 2013.

[43] Creswell J. Research design: Qualitative, quantitative and mixed methods approaches. Los Angeles (CA): Sage Publications; 2014.

[44] Takim R, Adnan H. Analysis of effectiveness measures of construction project success in Malaysia. Asian Soc Sci. 2008;4(7):74-91. 
[45] Office for National Statistics. Construction statistics. Newport: Office for National Statistics; 2012. (Construction statistics; No. 13, 2012 ed.)

[46] Field A. Discovering statistics using IBM SPSS statistic. 4th ed. Los Angeles (CA): Sage Publications; 2013.

[47] Takala J, Hämäläinen P, Saarela L, et al. Global estimates of the burden of injury and illness at work in 2012. J Occup Environ Hyg. 2014;11(5):326-337.

[48] Schwab K. The global competitiveness report 2017-2018. Geneva. World Economic Forum: 2017.

[49] Navendren D, Manu P, Shelbourn M, et al. Challenges to building information modelling implementation in UK: designers' perspectives. In: Raiden AB, Aboagye-Nimo E, editors. Proceedings of 30th annual ARCOM conference: 2014 Sep 1-3; Portsmouth. Reading: Association of Researchers in Construction Management; 2014. p. 733-742.

[50] Ayarkwa PJ, Dansoh A, Amoah P. Barriers to implementation of EMS in construction industry in Ghana. Int J Eng Sci. 2010;2(4):37-45.

[51] Igwe PU. Barriers to implementation of environmental management systems in tourism industry in Anambra State, Nigeria. Int J Eng Manag Sci. 2016;7(2):137144.

[52] Ministry of Labour, Invalids and Social Welfare. National programme on occupational safety and occupational health in period of 2011-2015. Hanoi: International Labour Organisation; 2012.

[53] Health and Safety Executive Construction Division. Underlying causes of construction fatal accidents -A comprehensive review of recent work to consolidate and summarise existing knowledge. Norwich: Her Majesty's Stationery Office; 2009. (Phase 1 report).

[54] Geminiani FL, Smallwood JJ, Wyk JJ. The effectiveness of the occupational health and safety $(\mathrm{OH} \& \mathrm{~S})$ inspectorate in South African construction [master's thesis]. Port Elizabeth: Nelson Mandela Metropolitan University; 2008. 


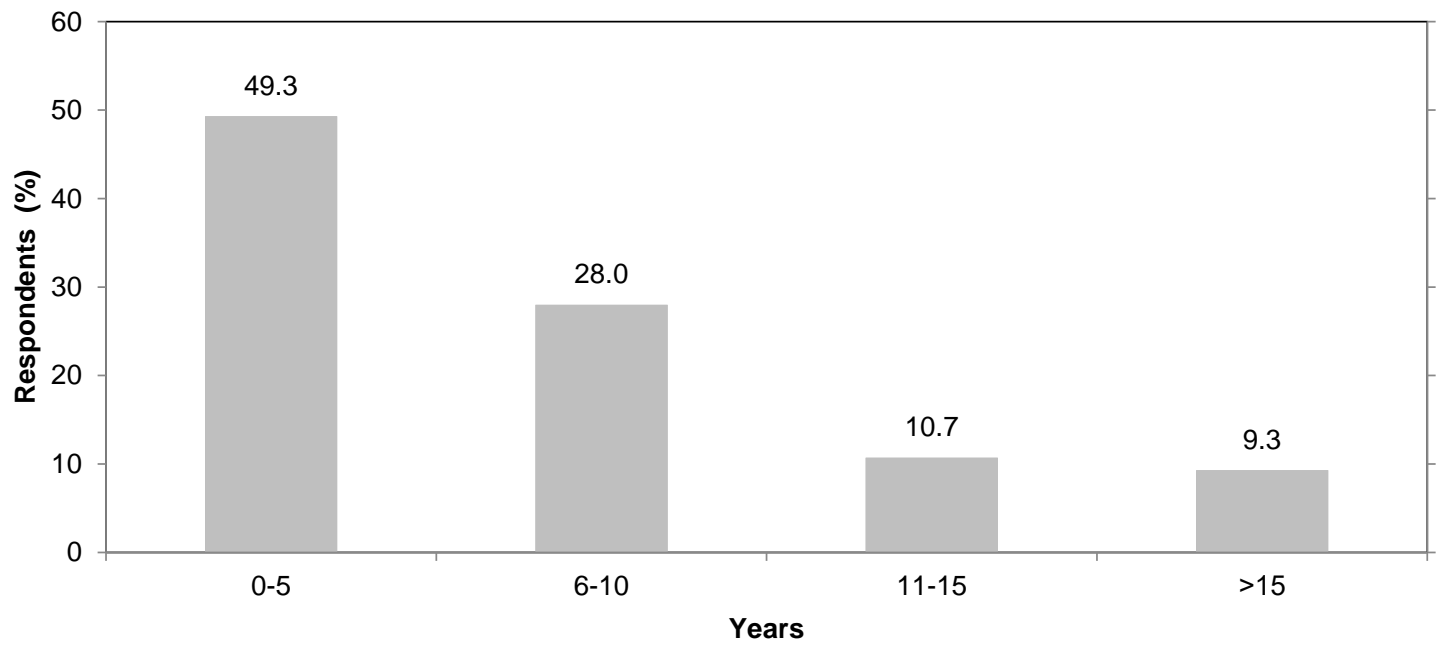

Figure 1: Respondents' working experience (Note: Sum of $\%$ is less than $100 \%$ due to non-response by some participant) 


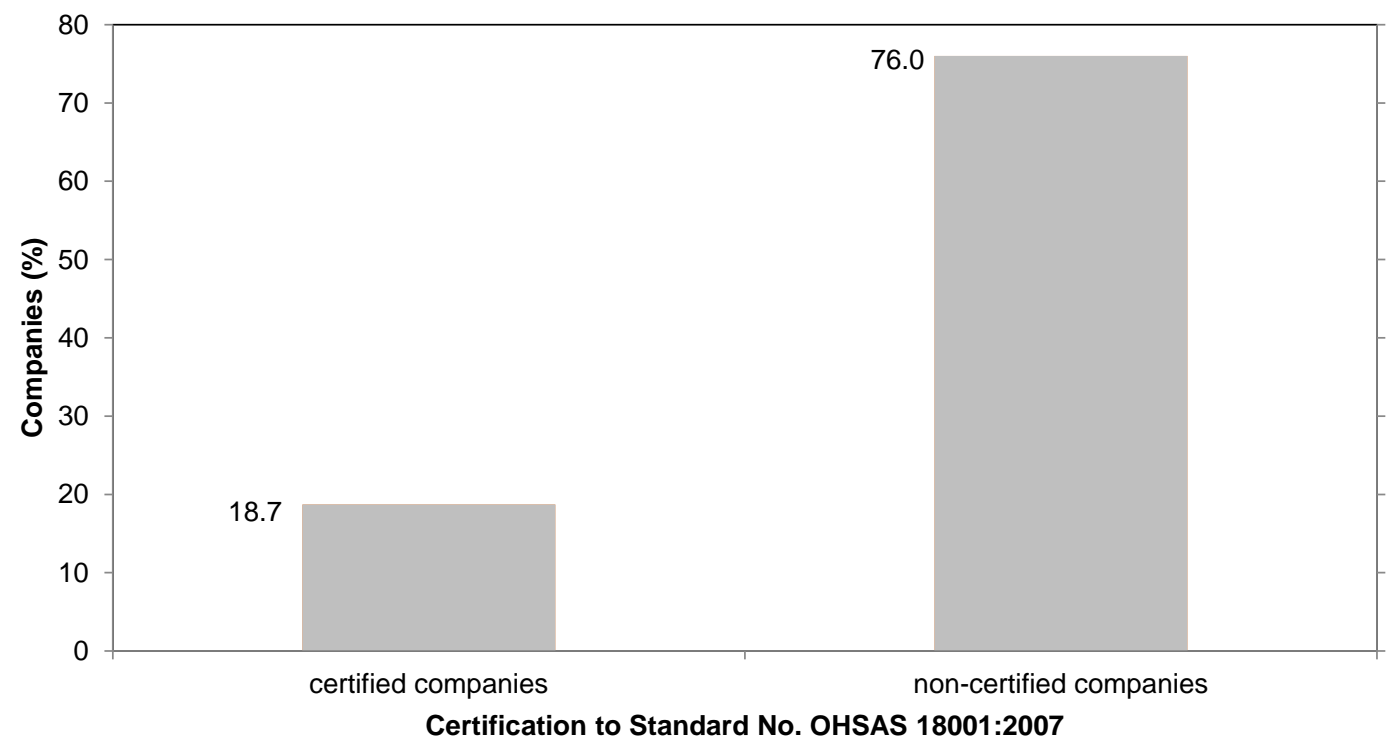

Figure 2: Certification to Standard No. OHSAS 18001: 2007 by construction companies (Note: Sum of \% is less than $100 \%$ due to non-response by some participants) 
Table 1. Summary of key elements of safety and health management systems.

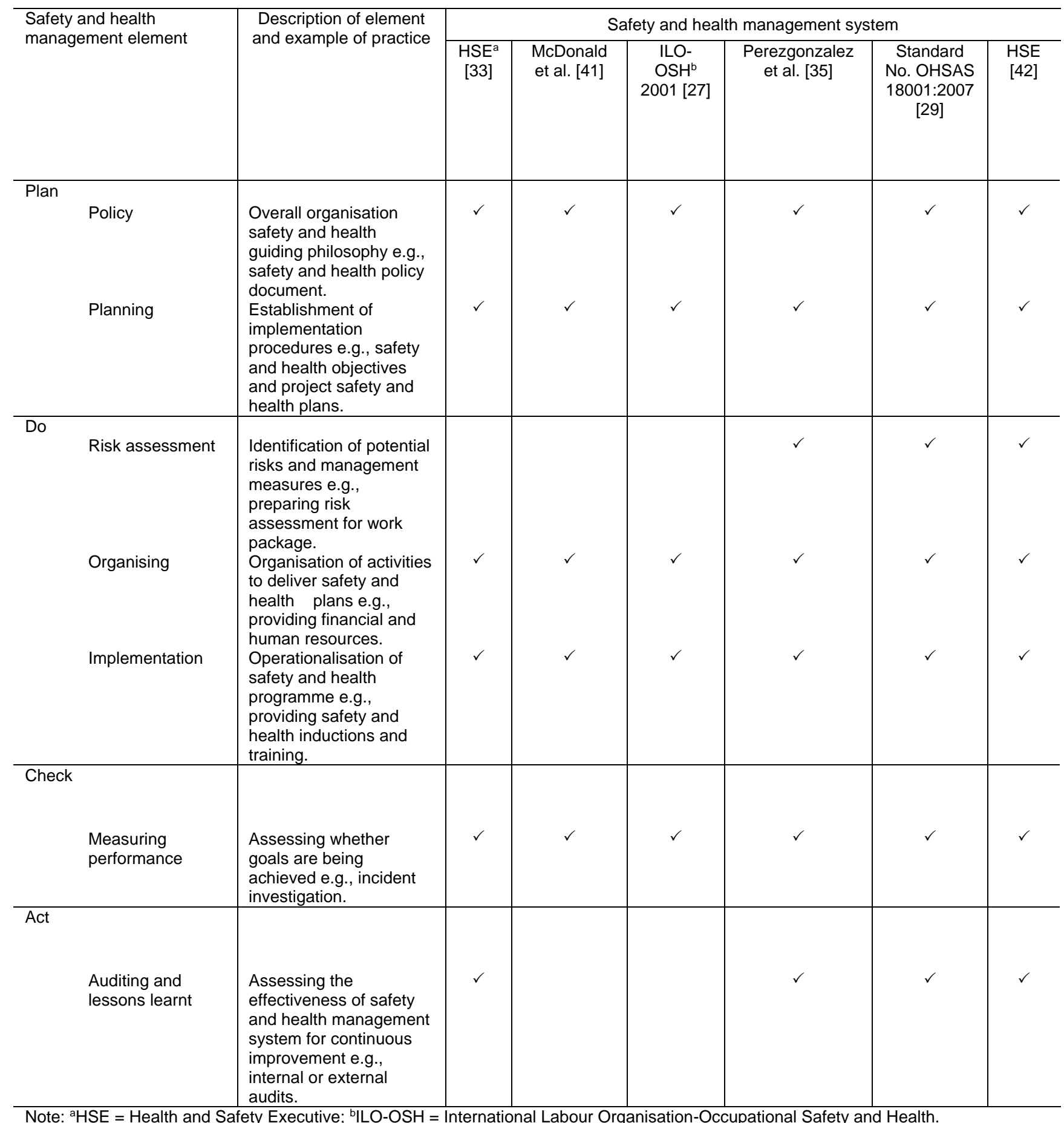

Ne ${ }^{~} \mathrm{HSE}=$ Health and Safety Executive; ${ }^{\circ}$ LO-OSH = International Labour Organisation-Occupational Safety and Health. 
Table 2. Response rate.

\begin{tabular}{l|c|c}
\hline Survey characteristics & Number & Percentage \\
\hline Distributed questionnaires & 320 & 100.0 of sample size \\
Returns & 75 & 23.4 of distributed questionnaires \\
Used for analysis & 75 & 100.0 of returns \\
\hline
\end{tabular}


Table 3. Respondents' professional roles.

\begin{tabular}{l|c|c}
\hline Professional role & Frequency & Percentage \\
\hline Company director/manager & 32 & 42.7 \\
Site manager & 2 & 2.7 \\
$\begin{array}{l}\text { Occupational safety and health } \\
\text { manager/supervisor }\end{array}$ & 3 & 4.0 \\
Site agent & 3 & 4.0 \\
Project manager & 5 & 6.7 \\
Site engineer & 5 & 6.7 \\
Procurement and administrative officer & 1 & 1.3 \\
Cost estimator/quantity surveyor & 24 & 32.0 \\
\hline
\end{tabular}


Table 4. Profile of the companies.

\begin{tabular}{|c|c|c|}
\hline Respondents' company profile & Frequency ${ }^{a, b}$ & Percentage $^{c}$ \\
\hline \multicolumn{3}{|l|}{ Size of company } \\
\hline Micro firm: $\leq 10$ employees & 38 & 50.7 \\
\hline Small firm: 11-50 employees & 16 & 21.3 \\
\hline Medium firm: 51-150 employees & 14 & 18.7 \\
\hline Large firm: >150 employees & 5 & 6.7 \\
\hline \multicolumn{3}{|l|}{ Age of company (in years) } \\
\hline$\leq 10$ & 34 & 45.3 \\
\hline $11-15$ & 19 & 25.3 \\
\hline$>15$ & 21 & 28.0 \\
\hline \multicolumn{3}{|l|}{ Sectors of work undertaken by company } \\
\hline Public sector works & 35 & 46.7 \\
\hline Private sector works & 31 & 41.3 \\
\hline \multicolumn{3}{|l|}{ Works undertaken by company } \\
\hline Building & 50 & 66.7 \\
\hline Civil engineering & 46 & 61.3 \\
\hline Electrical and mechanical & 9 & 12.0 \\
\hline \multicolumn{3}{|l|}{ Business class of registration (in $\mathrm{MWK}^{\mathrm{d}}$ ) } \\
\hline 2.5-30 million & 9 & 12 \\
\hline 50-75 million & 7 & 9.3 \\
\hline 100-200 million & 21 & 28.0 \\
\hline 500 million to $>$ one billion & 36 & 48.0 \\
\hline \multicolumn{3}{|l|}{ 2015/16 annual turnover (in MWK) } \\
\hline 0-10 million & 10 & 13.3 \\
\hline 11-75 million & 14 & 18.7 \\
\hline 76-200 million & 12 & 16.0 \\
\hline >201 million & 36 & 48.0 \\
\hline \multicolumn{3}{|c|}{$\begin{array}{l}\text { Note: }{ }^{a} \text { sum of frequency could be less than } 75 \text { due non-responses by some participants; }{ }^{\text {b }} \text { sum of contractors in the category of } \\
\text { registration is greater than } 75 \text { as some contractors are registered in both building and civil engineering categories; }{ }^{c} \text { Sum of } \% \text { could } \\
\text { be less than } 100 \% \text { due to non-response by some participants; }{ }^{d} \mathrm{MWK}=\text { Malawi Kwacha, EUR } 100=\text { MWK } 84,916.4, \text { USD } 100=\text { MWK } \\
71,892.1 \text {, the exchange rate used is the average August } 2017 \text { interbank exchange rate obtained from } \\
\text { https://www.oanda.com/currency/average. }\end{array}$} \\
\hline
\end{tabular}


Table 5. The extent of implementation of safety and health management practices.

\begin{tabular}{|c|c|c|c|c|c|}
\hline \multirow{2}{*}{$\begin{array}{l}\text { Safety and } \\
\text { health } \\
\text { management } \\
\text { element }\end{array}$} & \multicolumn{2}{|c|}{ Safety and health management practice } & \multirow[b]{2}{*}{ Frequency $^{b}$} & \multirow[b]{2}{*}{ Percentage $^{c}$} & \multirow[b]{2}{*}{$\begin{array}{l}\text { Extent of } \\
\text { implementation }\end{array}$} \\
\hline & $\begin{array}{l}\text { Practice } \\
\text { code }^{\mathrm{a}}\end{array}$ & Description of practice & & & \\
\hline Policy & $\begin{array}{l}\text { Pol1 } \\
\text { Pol2 }\end{array}$ & $\begin{array}{l}\text { A formal company safety and health policy } \\
\text { statement } \\
\text { A company director with overall } \\
\text { responsibility for safety and health }\end{array}$ & $\begin{array}{l}33 \\
31\end{array}$ & $\begin{array}{l}44.0 \\
41.3\end{array}$ & $\begin{array}{l}\text { Low } \\
\text { Low }\end{array}$ \\
\hline \multirow[t]{14}{*}{ Organising } & Org1 & $\begin{array}{l}\text { Providing safety and health supervisors on } \\
\text { sites }\end{array}$ & 39 & 52.0 & Moderate \\
\hline & Org2 & $\begin{array}{l}\text { Communicating safety and health } \\
\text { information to workers through newsletters, } \\
\text { leaflets, posters, etc. }\end{array}$ & 24 & 32.0 & Low \\
\hline & Org3 & $\begin{array}{l}\text { Engaging with workers on health and safety } \\
\text { issues e.g., health and safety meetings and } \\
\text { suggestion schemes }\end{array}$ & 53 & 70.7 & High \\
\hline & Org4 & $\begin{array}{l}\text { Networking with other companies' / } \\
\text { institutions' (insurance companies, } \\
\text { government offices) about health and safety } \\
\text { issues }\end{array}$ & 19 & 25.3 & Low \\
\hline & Org5 & $\begin{array}{l}\text { Propagating safety and health practices to } \\
\text { external stakeholders e.g., clients }\end{array}$ & 14 & 18.7 & Low \\
\hline & Org6 & A designated safety and health department & 12 & 16.0 & Low \\
\hline & Org7 & $\begin{array}{l}\text { Assessing the competence of workers and } \\
\text { subcontractors }\end{array}$ & 19 & 25.3 & Low \\
\hline & Org8 & $\begin{array}{l}\text { A company designated health and safety } \\
\text { budget }\end{array}$ & 26 & 34.7 & Low \\
\hline & Org9 & $\begin{array}{l}\text { Display of regulatory health and safety } \\
\text { posters on construction sites }\end{array}$ & 42 & 56.0 & Moderate \\
\hline & Org10 & $\begin{array}{l}\text { Display of company safety and health policy } \\
\text { on construction sites, company website, and } \\
\text { head/branch offices }\end{array}$ & 17 & 22.7 & Low \\
\hline & Org11 & $\begin{array}{l}\text { Provision of safety and health annual } \\
\text { reports }\end{array}$ & 11 & 14.7 & Low \\
\hline & Org12 & A designated safety and health manager & 21 & 29.0 & Low \\
\hline & Org13 & $\begin{array}{l}\text { Providing safety and health training for site } \\
\text { safety supervisors and site managers }\end{array}$ & 33 & 44.0 & Low \\
\hline & Org14 & $\begin{array}{l}\text { Providing training programmes for safety } \\
\text { manager(s) }\end{array}$ & 18 & 24.0 & Low \\
\hline \multirow[t]{5}{*}{$\begin{array}{l}\text { Risk } \\
\text { assessment }\end{array}$} & Risk1 & $\begin{array}{l}\text { Undertaking overall project risk assessments } \\
\text { before projects start }\end{array}$ & 44 & 58.7 & Moderate \\
\hline & Risk2 & $\begin{array}{l}\text { Designing site rules and measures to } \\
\text { mitigate assessed risks }\end{array}$ & 42 & 56.0 & Moderate \\
\hline & Risk3 & $\begin{array}{l}\text { Undertaking risk assessments for work } \\
\text { packages/operations before they start }\end{array}$ & 25 & 33.3 & Low \\
\hline & Risk4 & $\begin{array}{l}\text { Reviewing and updating risk assessments } \\
\text { during construction }\end{array}$ & 31 & 41.3 & Low \\
\hline & Risk5 & $\begin{array}{l}\text { Informing employees about hazards on sites } \\
\text { before work starts }\end{array}$ & 60 & 80.0 & High \\
\hline
\end{tabular}


Table 5. continued.

\begin{tabular}{|c|c|c|c|c|c|}
\hline \multirow{2}{*}{$\begin{array}{l}\text { Safety and } \\
\text { health } \\
\text { management } \\
\text { element }\end{array}$} & \multicolumn{2}{|c|}{ Safety and health management practice } & \multirow{2}{*}{ Frequency $^{b}$} & \multirow{2}{*}{ Percentage $^{c}$} & \multirow{2}{*}{$\begin{array}{c}\text { Extent of } \\
\text { implementation }\end{array}$} \\
\hline & $\begin{array}{c}\text { Practice } \\
\text { code }^{\mathrm{a}}\end{array}$ & Description of practice & & & \\
\hline \multirow[t]{11}{*}{ Implementing } & Impl1 & $\begin{array}{l}\text { Implementing site safety and health rules } \\
\text { and measures }\end{array}$ & 48 & 640 & Moderate \\
\hline & Impl2 & $\begin{array}{l}\text { Amending and correcting safety and health } \\
\text { plans during construction }\end{array}$ & 27 & 36.0 & Low \\
\hline & Impl3 & Rewarding workers for safe work behaviour & 13 & 17.3 & Low \\
\hline & $\begin{array}{l}\text { Impl4 } \\
\text { Impl5 }\end{array}$ & $\begin{array}{l}\text { Site inductions for workers } \\
\text { Training programmes for site workers }\end{array}$ & $\begin{array}{l}31 \\
44\end{array}$ & $\begin{array}{l}41.3 \\
58.7\end{array}$ & $\begin{array}{l}\text { Low } \\
\text { Moderate }\end{array}$ \\
\hline & Impl6 & $\begin{array}{l}\text { Carrying out site health and safety } \\
\text { inspections regularly }\end{array}$ & 44 & 58.7 & Moderate \\
\hline & Impl7 & $\begin{array}{l}\text { Provision of sanitation and welfare facilities } \\
\text { on sites (e.g., toilets, canteens, drinking } \\
\text { water) }\end{array}$ & 60 & 80.0 & High \\
\hline & Impl8 & Provision of personal protective equipment & 69 & 92.0 & High \\
\hline & Impl9 & Provision of first aid equipment on sites & 67 & 89.3 & High \\
\hline & Impl10 & $\begin{array}{l}\text { Disciplining workers for unsafe work } \\
\text { behaviour }\end{array}$ & 33 & 44.0 & Low \\
\hline & Impl11 & $\begin{array}{l}\text { Assigning safety and health supervisor(s) } \\
\text { on site }\end{array}$ & 33 & 44.0 & Low \\
\hline & Impl12 & $\begin{array}{l}\text { Conducting regular health checks for } \\
\text { employees }\end{array}$ & 28 & 37.3 & Low \\
\hline \multirow{5}{*}{$\begin{array}{l}\text { Measuring and } \\
\text { reviewing } \\
\text { performance }\end{array}$} & Meas\&rev1 & $\begin{array}{l}\text { Measuring safety and health performance } \\
\text { against set targets }\end{array}$ & 24 & 32.0 & Low \\
\hline & Meas\&rev2 & $\begin{array}{l}\text { Reviewing and updating safety and health } \\
\text { plans after projects completion }\end{array}$ & 25 & 33.3 & Low \\
\hline & Meas\&Rev3 & Keeping incident records on every project & 53 & 70.7 & High \\
\hline & Meas\&rev4 & $\begin{array}{l}\text { Investigating the causes of incidents, } \\
\text { accidents and near-misses }\end{array}$ & 46 & 61.3 & Moderate \\
\hline & Meas\&rev5 & $\begin{array}{l}\text { Publishing or sharing lessons learnt from } \\
\text { incident investigations across the company } \\
\text { or on projects }\end{array}$ & 20 & 26.7 & Low \\
\hline \multirow[t]{3}{*}{ Auditing } & Aud1 & $\begin{array}{l}\text { Undertaking periodic safety management } \\
\text { auditing }\end{array}$ & 25 & 33.3 & Low \\
\hline & Aud2 & $\begin{array}{l}\text { Use of external consultant for undertaking } \\
\text { safety management auditing }\end{array}$ & 9 & 12.0 & Low \\
\hline & Aud3 & $\begin{array}{l}\text { Use of in-house personnel for undertaking } \\
\text { safety management auditing }\end{array}$ & 33 & 44.0 & Low \\
\hline
\end{tabular}


Table 6. Association between certification to Standard No. OHSAS 18001: 2007 and implementation of safety and health practices.

\begin{tabular}{|c|c|c|c|c|c|c|c|c|c|c|c|c|}
\hline \multirow{2}{*}{$\begin{array}{l}\text { Safety and } \\
\text { health } \\
\text { management } \\
\text { practice }^{\mathrm{a}}\end{array}$} & \multirow{2}{*}{$\begin{array}{l}\text { Implementation } \\
\text { of practice }{ }^{\mathrm{b}}\end{array}$} & \multicolumn{3}{|c|}{$\begin{array}{l}\text { Standard No. OHSAS 18001: } \\
2007[29] \text { non-certified }\end{array}$} & \multicolumn{3}{|c|}{$\begin{array}{c}\text { Standard No. OHSAS 18001: } \\
\text { 2007[29] certified }\end{array}$} & \multicolumn{3}{|c|}{ Pearson's $\chi^{2}$} & \multicolumn{2}{|c|}{ Cramer's $\varphi_{\mathrm{c}}$} \\
\hline & & Count & $\begin{array}{c}\text { Expected } \\
\text { Count }\end{array}$ & $\begin{array}{l}\% \text { within } \\
\text { practice }\end{array}$ & Count & $\begin{array}{c}\text { Expected } \\
\text { Count }\end{array}$ & $\begin{array}{l}\% \text { within } \\
\text { practice }\end{array}$ & Value & $d f$ & $\begin{array}{c}p(2- \\
\text { sided })\end{array}$ & Value & $p$ \\
\hline \multirow[t]{2}{*}{ Pol1 } & 0 & $36^{c}$ & 32.1 & 90.0 & $4^{c}$ & 7.9 & 10.0 & 5.466 & 1 & 0.033 & 0.277 & 0.033 \\
\hline & 1 & $21^{d}$ & 24.9 & 67.7 & $10^{d}$ & 6.1 & 32.3 & & & & & \\
\hline \multirow[t]{2}{*}{ Org1 } & 0 & $31^{c}$ & 26.5 & 93.9 & $2^{\mathrm{c}}$ & 6.5 & 6.1 & 7.265 & 1 & 0.008 & 0.320 & 0.008 \\
\hline & 1 & $26^{d}$ & 30.5 & 68.4 & $12^{\mathrm{d}}$ & 7.5 & 31.6 & & & & & \\
\hline \multirow[t]{2}{*}{ Org2 } & 0 & $43^{c}$ & 39.3 & 87.8 & $6^{c}$ & 9.7 & 12.2 & $5.224^{\mathrm{e}}$ & 1 & 0.050 & 0.280 & 0.026 \\
\hline & 1 & $14^{d}$ & 17.7 & 63.6 & $8^{d}$ & 4.3 & 36.4 & & & & & \\
\hline \multirow[t]{2}{*}{ Org4 } & 0 & $45^{\mathrm{c}}$ & 41.6 & 86.5 & $7^{c}$ & 10.4 & 13.5 & $4.912^{\mathrm{e}}$ & 1 & 0.037 & 0.278 & 0.037 \\
\hline & 1 & $11^{d}$ & 14.4 & 61.1 & $7^{d}$ & 3.6 & 38.9 & & & & & \\
\hline \multirow[t]{2}{*}{ Org6 } & 0 & $52^{c}$ & 47.4 & 88.1 & $7^{c}$ & 11.6 & 11.9 & $11.221^{\mathrm{e}}$ & 1 & 0.001 & 0.438 & 0.001 \\
\hline & 1 & $5^{d}$ & 9.6 & 41.7 & $7^{d}$ & 2.4 & 58.3 & & & & & \\
\hline \multirow[t]{2}{*}{ Org11 } & 0 & $53^{c}$ & 49.0 & 86.9 & $8^{c}$ & 12.0 & 13.1 & $9.634^{\mathrm{e}}$ & 1 & 0.003 & 0.410 & 0.003 \\
\hline & 1 & $4^{d}$ & 8.0 & 40.0 & $6^{d}$ & 2.0 & 60.0 & & & & & \\
\hline \multirow[t]{2}{*}{ PIn1 } & 0 & $27^{c}$ & 23.3 & 93.1 & $2^{c}$ & 5.7 & 6.9 & 5.091 & 1 & 0.033 & 0.268 & 0.033 \\
\hline & 1 & $30^{d}$ & 33.7 & 71.4 & $12^{d}$ & 8.3 & 28.6 & & & & & \\
\hline \multirow[t]{2}{*}{ PIn4 } & 0 & $37^{c}$ & 32.9 & 90.2 & $4^{c}$ & 8.1 & 9.8 & 6.083 & 1 & 0.018 & 0.293 & 0.018 \\
\hline & 1 & $20^{d}$ & 24.1 & 66.7 & $10^{d}$ & 5.9 & 33.3 & & & & & \\
\hline \multirow[t]{2}{*}{ Imp11 } & 0 & $36^{c}$ & 31.3 & 92.3 & $3^{c}$ & 7.7 & 7.7 & 7.905 & 1 & 0.007 & 0.334 & 0.007 \\
\hline & 1 & $21^{d}$ & 25.7 & 65.6 & $11^{d}$ & 6.3 & 34.4 & & & & & \\
\hline \multicolumn{13}{|c|}{ 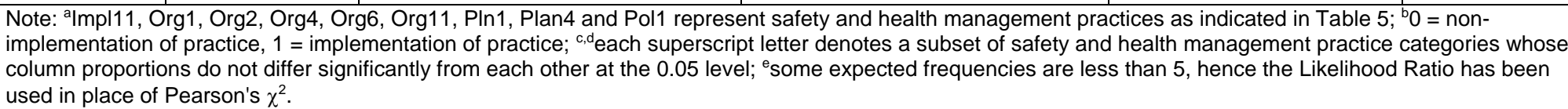 } \\
\hline
\end{tabular}


Table 7. Association between the company age and implementation of safety and health practices.

\begin{tabular}{|c|c|c|c|c|c|c|c|c|c|c|c|c|c|c|c|}
\hline \multirow{2}{*}{$\begin{array}{l}\text { Safety and } \\
\text { health } \\
\text { management } \\
\text { practice }^{\mathrm{a}}\end{array}$} & \multirow{2}{*}{$\begin{array}{l}\text { Implementation } \\
\text { of practice }\end{array}$} & \multicolumn{3}{|c|}{$\leq 10$ years } & \multicolumn{3}{|c|}{$11-50$ years } & \multicolumn{3}{|c|}{$>50$ years } & \multicolumn{3}{|c|}{ Pearson's $\chi^{2}$} & \multicolumn{2}{|c|}{ Cramer's $\varphi_{\mathrm{c}}$} \\
\hline & & Count & $\begin{array}{c}\text { Expected } \\
\text { Count }\end{array}$ & $\begin{array}{l}\% \text { within } \\
\text { practice }\end{array}$ & Count & $\begin{array}{l}\text { Expected } \\
\text { Count }\end{array}$ & $\begin{array}{l}\% \text { within } \\
\text { practice }\end{array}$ & Count & $\begin{array}{c}\text { Expected } \\
\text { Count }\end{array}$ & $\begin{array}{l}\% \text { within } \\
\text { practice }\end{array}$ & Value & $d f$ & $\begin{array}{l}p(2- \\
\text { sided })\end{array}$ & Value & $p$ \\
\hline \multirow[t]{2}{*}{ Pol2 } & 0 & $25^{c}$ & 19.8 & 58.1 & $10^{c}$ & 11.0 & 23.3 & $8^{c}$ & 12.2 & 18.6 & 7.011 & 2 & 0.034 & 0.308 & 0.034 \\
\hline & 1 & $9^{d}$ & 14.2 & 29.0 & $9^{c}$ & 8.0 & 29.0 & $13^{d}$ & 8.8 & 41.9 & & & & & \\
\hline \multirow[t]{2}{*}{ Org1 } & 0 & $22^{c}$ & 16.1 & 62.9 & $9^{c}$ & 9.0 & 25.7 & $4^{c}$ & 9.9 & 11.4 & 10.857 & 2 & 0.004 & 0.383 & 0.004 \\
\hline & 1 & $12^{\mathrm{d}}$ & 17.9 & 30.8 & $10^{c}$ & 10.0 & 25.6 & $17^{d}$ & 11.1 & 43.6 & & & & & \\
\hline \multirow[t]{2}{*}{ Org3 } & 0 & $16^{c}$ & 10.1 & 72.7 & $5^{c}$ & 5.6 & 22.7 & $1^{\mathrm{c}}$ & 6.2 & 4.5 & 11.260 & 2 & 0.003 & 0.390 & 0.003 \\
\hline & 1 & $18^{d}$ & 23.9 & 34.6 & $14^{c}$ & 13.4 & 26.9 & $20^{d}$ & 14.8 & 38.5 & & & & & \\
\hline \multirow[t]{2}{*}{ Org7 } & 0 & $28^{c}$ & 25.3 & 50.9 & $16^{c}$ & 14.1 & 29.1 & $11^{c}$ & 15.6 & 20.0 & 7.420 & 2 & 0.025 & 0.317 & 0.025 \\
\hline & 1 & $6^{c}$ & 8.7 & 31.6 & $3^{c}$ & 4.9 & 15.8 & $10^{d}$ & 5.4 & 52.6 & & & & & \\
\hline \multirow[t]{2}{*}{ Org8 } & 0 & $26^{c}$ & 22.1 & 54.2 & $15^{c}$ & 12.3 & 31.3 & $7^{c}$ & 13.6 & 14.6 & 12.824 & 2 & 0.001 & 0.416 & 0.001 \\
\hline & 1 & $8^{c}$ & 11.9 & 30.8 & $4^{c}$ & 6.7 & 15.4 & $14^{d}$ & 7.4 & 53.8 & & & & & \\
\hline \multirow[t]{2}{*}{ Org13 } & 0 & $21^{c}$ & 19.3 & 50.0 & $14^{\mathrm{C}}$ & 10.8 & 33.3 & $7^{c}$ & 11.9 & 16.7 & 7.260 & 2 & 0.028 & 0.313 & 0.028 \\
\hline & 1 & $13^{c}$ & 14.7 & 40.6 & $5^{c}$ & 8.2 & 15.6 & $14^{d}$ & 9.1 & 43.8 & & & & & \\
\hline \multirow[t]{2}{*}{ Risk2 } & 0 & $17^{c}$ & 15.2 & 51.5 & $12^{c}$ & 8.5 & 36.4 & $4^{c}$ & 9.4 & 12.1 & 8.599 & 2 & 0.015 & 0.341 & 0.015 \\
\hline & 1 & $17^{c}$ & 18.8 & 41.5 & $7^{c}$ & 10.5 & 17.1 & $17^{d}$ & 11.6 & 41.5 & & & & & \\
\hline \multirow[t]{2}{*}{ PIn1 } & 0 & $15^{c}$ & 13.8 & 50.0 & $11^{\mathrm{C}}$ & 7.7 & 36.7 & $4^{c}$ & 8.5 & 13.3 & 6.579 & 2 & 0.037 & 0.298 & 0.037 \\
\hline & 1 & $19^{c}$ & 20.2 & 43.2 & $8^{c}$ & 11.3 & 18.2 & $17^{d}$ & 12.5 & 38.6 & & & & & \\
\hline \multirow[t]{2}{*}{ Impl11 } & 0 & $24^{c}$ & 18.4 & 60.0 & $11^{\mathrm{C}}$ & 10.3 & 27.5 & $5^{c}$ & 11.4 & 12.5 & 11.988 & 2 & 0.003 & 0.396 & 0.003 \\
\hline & 1 & $10^{d}$ & 15.6 & 29.4 & $8^{c}$ & 8.7 & 23.5 & $16^{d}$ & 9.6 & 47.1 & & & & & \\
\hline \multirow[t]{2}{*}{ Aud1 } & 0 & $27^{c}$ & 22.5 & 55.1 & $13^{c}$ & 12.6 & 26.5 & $9^{c}$ & 13.9 & 18.4 & 7.810 & 2 & 0.018 & 0.325 & 0.018 \\
\hline & 1 & $7^{d}$ & 11.5 & 28.0 & $6^{c}$ & 6.4 & 24.0 & $12^{d}$ & 7.1 & 48.0 & & & & & \\
\hline
\end{tabular}


Table 8. Association between company size and implementation of safety and health practices.

\begin{tabular}{|c|c|c|c|c|c|c|c|c|c|c|c|c|c|c|c|c|c|c|}
\hline \multirow{2}{*}{$\begin{array}{l}\text { Safety and } \\
\text { health } \\
\text { management } \\
\text { practice }^{\mathrm{a}}\end{array}$} & \multirow[b]{2}{*}{$\begin{array}{l}\text { Implementation } \\
\text { of practice }\end{array}$} & \multicolumn{3}{|c|}{ Micro } & \multicolumn{3}{|c|}{ Small } & \multicolumn{3}{|c|}{ Medium } & \multicolumn{3}{|c|}{ Large } & \multicolumn{3}{|c|}{ Likelihood Ratiod $^{d}$} & \multicolumn{2}{|c|}{ Cramer's $\varphi_{\mathrm{c}}$} \\
\hline & & Count & $\begin{array}{l}\text { Exp. }^{c} \\
\text { Count }\end{array}$ & $\begin{array}{c}\% \\
\text { within } \\
\text { practice }\end{array}$ & Count & $\begin{array}{l}\text { Exp. } \\
\text { Count }\end{array}$ & $\begin{array}{c}\% \\
\text { within } \\
\text { practice }\end{array}$ & Count & $\begin{array}{l}\text { Exp. } \\
\text { Count }\end{array}$ & $\begin{array}{c}\% \\
\text { within } \\
\text { practice }\end{array}$ & Count & $\begin{array}{l}\text { Exp. } \\
\text { Count }\end{array}$ & $\begin{array}{l}\% \text { within } \\
\text { practice }\end{array}$ & Value & $d f$ & $\begin{array}{c}p(2- \\
\text { sided })\end{array}$ & Value & $p$ \\
\hline \multirow[t]{2}{*}{ Pol1 } & 0 & $27^{e}$ & 21.9 & 64.3 & $11^{\mathrm{e}}$ & 9.2 & 26.2 & $4^{e}$ & 8.1 & 9.5 & $0^{e}$ & 2.9 & 0.0 & 17.182 & 3 & 0.001 & 0.457 & 0.001 \\
\hline & 1 & $11^{\dagger}$ & 16.1 & 35.5 & $5^{e}$ & 6.8 & 16.1 & $10^{f}$ & 5.9 & 32.3 & $5^{f}$ & 2.1 & 16.1 & & & & & \\
\hline \multirow[t]{2}{*}{ Pol2 } & 0 & $27^{e}$ & 21.9 & 64.3 & $8^{e}$ & 9.2 & 19.0 & $4^{e}$ & 8.1 & 9.5 & $3^{e}$ & 2.9 & 7.1 & 8.146 & 3 & 0.042 & 0.332 & 0.042 \\
\hline & 1 & $11^{\dagger}$ & 16.1 & 35.5 & $8^{e}$ & 6.8 & 25.8 & $10^{f}$ & 5.9 & 32.3 & $2^{\mathrm{e}}$ & 2.1 & 6.5 & & & & & \\
\hline \multirow[t]{2}{*}{ Org1 } & 0 & $27^{e}$ & 18.2 & 77.1 & $6^{e}$ & 7.7 & 17.1 & $2^{\mathrm{e}}$ & 6.7 & 5.7 & $0^{\mathrm{e}}$ & 2.4 & 0.0 & 22.695 & 3 & 0.000 & 0.521 & 0.000 \\
\hline & 1 & $11^{\dagger}$ & 19.8 & 28.9 & $10^{\mathrm{e}}$ & 8.3 & 26.3 & $12^{f}$ & 7.3 & 31.6 & $5^{\dagger}$ & 2.6 & 13.2 & & & & & \\
\hline \multirow[t]{2}{*}{ Org2 } & 0 & $30^{e}$ & 26.0 & 60.0 & $14^{\mathrm{e}}$ & 11.0 & 28.0 & $4^{\mathrm{e}}$ & 9.6 & 8.0 & $2^{\mathrm{e}}$ & 3.4 & 4.0 & 16.320 & 3 & 0.001 & 0.480 & 0.001 \\
\hline & 1 & $8^{f}$ & 12.0 & 34.8 & $2^{\mathrm{e}}$ & 5.0 & 8.7 & $10^{f}$ & 4.4 & 43.5 & $3^{e}$ & 1.6 & 13.0 & & & & & \\
\hline \multirow[t]{2}{*}{ Org3 } & 0 & $18^{e}$ & 11.5 & 81.8 & $4^{\mathrm{e}}$ & 4.8 & 18.2 & $0^{\mathrm{e}}$ & 4.2 & 0.0 & $0^{\mathrm{e}}$ & 1.5 & 0.0 & 18.786 & 3 & 0.003 & 0.434 & 0.003 \\
\hline & 1 & $20^{\dagger}$ & 26.5 & 39.2 & $12^{\mathrm{e}}$ & 11.2 & 23.5 & $14^{f}$ & 9.8 & 27.5 & $5^{e}$ & 3.5 & 9.8 & & & & & \\
\hline \multirow[t]{2}{*}{ Org4 } & 0 & $34^{e}$ & 28.5 & 63.0 & $10^{\mathrm{e}}$ & 11.3 & 18.5 & $6^{e}$ & 10.5 & 11.1 & $4^{e}$ & 3.8 & 7.4 & 12.182 & 3 & 0.005 & 0.418 & 0.005 \\
\hline & 1 & $4^{f}$ & 9.5 & 22.2 & $5^{e}$ & 3.8 & 27.8 & $8^{f}$ & 3.5 & 44.4 & $1^{\mathrm{e}}$ & 1.3 & 5.6 & & & & & \\
\hline \multirow[t]{2}{*}{ Org5 } & 0 & $36^{e}$ & 30.7 & 61.0 & $10^{e}$ & 12.9 & 16.9 & $9^{e}$ & 11.3 & 15.3 & $4^{\mathrm{e}}$ & 4.0 & 6.8 & 11.270 & 3 & 0.014 & 0.383 & 0.014 \\
\hline & 1 & $2^{f}$ & 7.3 & 14.3 & $6^{f}$ & 3.1 & 42.9 & $5^{\mathrm{e}}$ & 2.7 & 35.7 & $1^{\mathrm{e}}$ & 1.0 & 7.1 & & & & & \\
\hline \multirow[t]{2}{*}{ Org6 } & 0 & $36^{\mathrm{e}}$ & 32.3 & 58.1 & $15^{\mathrm{e}}$ & 13.6 & 24.2 & $8^{e}$ & 11.9 & 12.9 & $3^{\mathrm{e}}$ & 4.2 & 4.8 & 12.885 & 3 & 0.003 & 0.449 & 0.003 \\
\hline & 1 & $2^{f}$ & 5.7 & 18.2 & $1^{\mathrm{e}}$ & 2.4 & 9.1 & $6^{f}$ & 2.1 & 54.5 & $2^{\mathrm{e}}$ & 0.8 & 18.2 & & & & & \\
\hline \multirow[t]{2}{*}{ Org8 } & 0 & $31^{e}$ & 24.5 & 66.0 & $12^{\mathrm{e}}$ & 10.3 & 25.5 & $3^{e}$ & 9.0 & 6.4 & $1^{\mathrm{e}}$ & 3.2 & 2.1 & 21.219 & 3 & 0.000 & 0.539 & 0.000 \\
\hline & 1 & $7^{f}$ & 13.5 & 26.9 & $4^{e}$ & 5.7 & 15.4 & $11^{\dagger}$ & 5.0 & 42.3 & $4^{f}$ & 1.8 & 15.4 & & & & & \\
\hline \multirow[t]{2}{*}{ Org11 } & 0 & $37^{e}$ & 32.3 & 59.7 & $14^{\mathrm{e}}$ & 13.6 & 22.6 & $8^{e}$ & 11.9 & 12.9 & $3^{e}$ & 4.2 & 4.8 & 14.732 & 3 & 0.002 & 0.462 & 0.002 \\
\hline & 1 & $1^{f}$ & 5.7 & 9.1 & $2^{\mathrm{e}}$ & 2.4 & 18.2 & $6^{f}$ & 2.1 & 54.5 & $2^{\mathrm{e}}$ & 0.8 & 18.2 & & & & & \\
\hline
\end{tabular}


Table 8. continued.

\begin{tabular}{|c|c|c|c|c|c|c|c|c|c|c|c|c|c|c|c|c|c|c|}
\hline \multirow{2}{*}{$\begin{array}{l}\text { Safety and } \\
\text { health } \\
\text { management } \\
\text { practice }^{\mathrm{a}}\end{array}$} & \multirow[b]{2}{*}{$\begin{array}{l}\text { Implementation } \\
\text { of practice }\end{array}$} & \multicolumn{3}{|c|}{ Micro } & \multicolumn{3}{|c|}{ Small } & \multicolumn{3}{|c|}{ Medium } & \multicolumn{3}{|c|}{ Large } & \multicolumn{3}{|c|}{ Likelihood Ratio $^{d}$} & \multicolumn{2}{|c|}{ Cramer's $\varphi_{c}$} \\
\hline & & Count & $\begin{array}{l}\text { Exp. }^{\mathrm{c}} \\
\text { Count }\end{array}$ & $\begin{array}{c}\% \\
\text { within } \\
\text { practice }\end{array}$ & Count & $\begin{array}{l}\text { Exp. } \\
\text { Count }\end{array}$ & $\begin{array}{c}\% \\
\text { within } \\
\text { practice }\end{array}$ & Count & $\begin{array}{l}\text { Exp. } \\
\text { Count }\end{array}$ & $\begin{array}{c}\% \\
\text { within } \\
\text { practice }\end{array}$ & Count & $\begin{array}{l}\text { Exp. } \\
\text { Count }\end{array}$ & $\begin{array}{l}\% \text { within } \\
\text { practice }\end{array}$ & Value & $d f$ & $\begin{array}{l}p(2- \\
\text { sided })\end{array}$ & Value & $p$ \\
\hline \multirow[t]{2}{*}{ Org12 } & 0 & $31^{\mathrm{e}}$ & 27.1 & 59.6 & $13^{\mathrm{e}}$ & 11.4 & 25.0 & $5^{e}$ & 10.0 & 9.6 & $3^{\mathrm{e}}$ & 3.6 & 5.8 & 10.879 & 3 & 0.008 & 0.400 & 0.008 \\
\hline & 1 & $7^{\dagger}$ & 10.9 & 33.3 & $3^{e}$ & 4.6 & 14.3 & $9^{f}$ & 4.0 & 42.9 & $2^{e}$ & 1.4 & 9.5 & & & & & \\
\hline \multirow[t]{2}{*}{ Org13 } & 0 & $28^{\mathrm{e}}$ & 21.3 & 68.3 & $9^{e}$ & 9.0 & 22.0 & $3^{e}$ & 7.9 & 7.3 & $1^{\mathrm{e}}$ & 2.8 & 2.4 & 14.803 & 3 & 0.002 & 0.442 & 0.002 \\
\hline & 1 & $10^{f}$ & 16.7 & 31.3 & $7^{e}$ & 7.0 & 21.9 & $11^{\dagger}$ & 6.1 & 34.4 & $4^{e}$ & 2.2 & 12.5 & & & & & \\
\hline \multirow[t]{2}{*}{ Org14 } & 0 & $31^{\mathrm{e}}$ & 28.6 & 56.4 & $14^{\mathrm{e}}$ & 12.1 & 25.5 & $6^{\mathrm{e}}$ & 10.5 & 10.9 & $4^{e}$ & 3.8 & 7.3 & 9.058 & 3 & 0.017 & 0.372 & 0.017 \\
\hline & 1 & $7^{e}$ & 9.4 & 38.9 & $2^{\mathrm{e}}$ & 3.9 & 11.1 & $8^{f}$ & 3.5 & 44.4 & $1^{e}$ & 1.2 & 5.6 & & & & & \\
\hline \multirow[t]{2}{*}{ PIn1 } & 0 & $21^{\mathrm{e}}$ & 15.6 & 70.0 & $6^{e}$ & 6.6 & 20.0 & $3^{\mathrm{e}}$ & 5.8 & 10.0 & $0^{\mathrm{e}}$ & 2.1 & 0.0 & 10.896 & 3 & 0.027 & 0.350 & 0.027 \\
\hline & 1 & $17^{f}$ & 22.4 & 39.5 & $10^{e}$ & 9.4 & 23.3 & $11^{\mathrm{e}}$ & 8.2 & 25.6 & $5^{e}$ & 2.9 & 11.6 & & & & & \\
\hline \multirow[t]{2}{*}{ PIn4 } & 0 & $28^{\mathrm{e}}$ & 22.4 & 65.1 & $9^{e}$ & 9.4 & 20.9 & $5^{e}$ & 8.2 & 11.6 & $1^{\mathrm{e}}$ & 2.9 & 2.3 & 9.887 & 3 & 0.018 & 0.365 & 0.018 \\
\hline & 1 & $10^{f}$ & 15.6 & 33.3 & $7^{e}$ & 6.6 & 23.3 & $9^{f}$ & 5.8 & 30.0 & $4^{e}$ & 2.1 & 13.3 & & & & & \\
\hline \multirow[t]{2}{*}{ PIn5 } & 0 & $32^{\mathrm{e}}$ & 27.1 & 61.5 & $11^{\mathrm{e}}$ & 11.4 & 21.2 & $6^{\mathrm{e}}$ & 10.0 & 11.5 & $3^{\mathrm{e}}$ & 3.6 & 5.8 & 8.733 & 3 & 0.026 & 0.351 & 0.026 \\
\hline & 1 & $6^{f}$ & 10.9 & 28.6 & $5^{e}$ & 4.6 & 23.8 & $8^{f}$ & 4.0 & 38.1 & $2^{\mathrm{e}}$ & 1.4 & 9.5 & & & & & \\
\hline \multirow[t]{2}{*}{ Impl1 } & 0 & $20^{\mathrm{e}}$ & 14.1 & 74.1 & $4^{\mathrm{e}}$ & 5.9 & 14.8 & $3^{\mathrm{e}}$ & 5.2 & 11.1 & $0^{\mathrm{e}}$ & 1.8 & 0.0 & 11.080 & 3 & 0.023 & 0.358 & 0.023 \\
\hline & 1 & $18^{f}$ & 23.9 & 39.1 & $12^{\mathrm{e}}$ & 10.1 & 26.1 & $11^{\mathrm{e}}$ & 8.8 & 23.9 & $5^{e}$ & 3.2 & 10.9 & & & & & \\
\hline \multirow[t]{2}{*}{ Impl11 } & 0 & $28^{e}$ & 20.8 & 70.0 & $10^{\mathrm{e}}$ & 8.8 & 25.0 & $2^{\mathrm{e}}$ & 7.7 & 5.0 & $0^{e}$ & 2.7 & 0.0 & 24.073 & 3 & 0.000 & 0.539 & 0.000 \\
\hline & 1 & $10^{f}$ & 17.2 & 30.3 & $6^{e}$ & 7.2 & 18.2 & $12^{f}$ & 6.3 & 36.4 & $5^{\dagger}$ & 2.3 & 15.2 & & & & & \\
\hline \multirow[t]{2}{*}{ Impl12 } & 0 & $29^{e}$ & 23.9 & 63.0 & $9^{e}$ & 10.1 & 19.6 & $4^{e}$ & 8.8 & 8.7 & $4^{e}$ & 3.2 & 8.7 & 10.908 & 3 & 0.010 & 0.387 & 0.010 \\
\hline & 1 & $9^{f}$ & 14.1 & 33.3 & $7^{e}$ & 5.9 & 25.9 & $10^{f}$ & 5.2 & 37.0 & $1^{e}$ & 1.8 & 3.7 & & & & & \\
\hline \multirow[t]{2}{*}{ Audit1 } & 0 & $30^{e}$ & 25.0 & 62.5 & $11^{\mathrm{e}}$ & 10.5 & 22.9 & $4^{e}$ & 9.2 & 8.3 & $3^{e}$ & 3.3 & 6.3 & 11.358 & 3 & 0.007 & 0.400 & 0.007 \\
\hline & 1 & $8^{f}$ & 13.0 & 32.0 & $5^{\mathrm{e}}$ & 5.5 & 20.0 & $10^{f}$ & 4.8 & 40.0 & $2^{\mathrm{e}}$ & 1.7 & 8.0 & & & & & \\
\hline
\end{tabular}


Table 9. Summary of the of implementation level of safety and health management practices.

\begin{tabular}{l|c|c|c|c|c}
\hline \multirow{2}{*}{$\begin{array}{l}\text { Safety and health management } \\
\text { element }\end{array}$} & \multicolumn{4}{|c}{ Extent of implementation of safety and health management practices } \\
\cline { 2 - 6 } & Low & Moderate & High & Total & Low implementation (\%) \\
\hline Policy & 11 & 0 & 0 & 2 & 100.0 \\
Organising & 2 & 2 & 1 & 1 & 78.6 \\
Risk assessment & 2 & 2 & 1 & 5 & 40.0 \\
Planning & 6 & 3 & 3 & 12 & 40.0 \\
Implementation & 3 & 1 & 1 & 5 & 50.0 \\
Measurement and reviewing & 3 & 0 & 0 & 3 & 60.0 \\
Auditing & 29 & 10 & 7 & 46 & 100.0 \\
\hline Total & & & & 5 \\
\hline
\end{tabular}

